\title{
An Analysis on the Blended Teaching Reform on English Oral Courses
}

\author{
Qi Kang \\ Dalian Neusoft University of Information, No.8 Software Park Road, Dalian, Liaoning, China \\ kangqi@neusoft.edu.cn
}

\begin{abstract}
Keywords: Educational Reform, Blended Teaching Model, English Oral Course.
Abstract. With the development of information technology in the recent decades, the higher educational institutions in China are facing challenges to undertake educational reforms. It is necessary for universities to fulfill the tasks of instilling knowledge and cultivating abilities by designing scientific and systematic teaching content and innovative teaching methods. Under the background of the higher educational reform, Dalian Neusoft University of Information has introduced the concept of blended teaching into its curriculum construction and Foreign Language Institute has set an example by designing a series of innovative English oral courses, namely Pronunciation and Communication, Current Issue Discussion, Public Speaking and Debate. So far, the new concept of blended teaching has received a wide recognition in cultivating students' independent learning ability and improving their comprehensive qualities as well.
\end{abstract}

\section{Introduction to blended teaching model}

Blended teaching model is an integration of both online and offline teaching activities. It has become the latest educational programme to make an impact on classroom teaching. In blended classroom, students gain necessary knowledge before class and apply that knowledge under the guidance of the teacher during class, which maximizes student-teacher interaction in the classroom. [1] This contrasts with the traditional classroom model where instruction is provided during class time and student-teacher interaction is typically minimal. So in the traditional classroom, students are not effectively engaged in the lecture-styled instructions, while the blended-teaching model is associated with improved academic performance and is well-received by students. With the introduction of blended teaching concept into China, it has gained a great popularity among teaching institutions and kept on developing with the emergence of new teaching technologies.

\section{Course introduction}

The English oral courses are the professional core courses open to the first two-year English major students in DNUI. It consists of four interrelated phases, namely Pronunciation and Communication, Current Issue Discussion, Public Speaking and Debate. It is an educational reform at the level of course construction with self-designed teaching content and innovative teaching methods. In order to enhance students' abilities in language application, critical thinking, cross-cultural communication and self-study, with the design of pre-class, in-class, after-class activities and the project-based tasks, the oral courses function both in facilitating students' future study and enhancing their comprehensive qualities.

\section{Innovation in course construction}

\subsection{Introduction of teaching objectives}

The series of English Oral courses are designed with increasing difficulties and are open to English major students during their first two academic years. The course of Pronunciation and Communication aims at introducing the basic rules for English pronunciation, such as vowels and consonants, skills of linking and fricative etc. It is designed to help students acquire correct reading skills and cultivate abilities to effectively communicate with others on daily topics. Students are expected to master the correct and standard English pronunciation, learn to use natural and appropriate intonation to express ideas, fulfill the goal of effective communication and finally, cultivate good reading habits. The course of Current Issue Discussion aims to improve students' 
abilities in oral English communication. The task of analyzing and discussing current issues broadens students' international perspectives and keep them informed of the latest trends in politics, business, science and environment etc. The course focuses on students' English oral communication and content construction through teamwork and group discussion. The course of Public Speaking guides students to prepare speeches step by step, from outline design to speech presentation. The section of critical thinking enables students to identify and sort out useful information. Finally, a variety of speech types, such as informative speech, persuasive speech and impromptu speech are introduced. Students learn to do logical thinking, dialectical thinking and creative thinking in this course. The final course of Debate makes an introduction of the British parliamentary debating system. Through systematic learning, students can improve their oral English to accurately analyze and clearly express ideas for debating activities. They are expected to master the skills and strategies of debating, together with logical thinking, dialectical thinking and creative thinking abilities.

\subsection{Traditional teaching vs. innovative teaching}

Traditional education refers to the long-established customs that society traditionally use in schools. It is described as being teacher-oriented in a lecture style and inflexible. It requires students to attend classes in person and seek additional guidance from professors, which is more readily available on campus. Traditional classes may be a better choice for students who enjoy interacting with teachers and professors face-to-face. Modern information-based teaching refers to the application of information technology to improve teaching quality and efficiency. Students change from passively accepting knowledge to actively learn it. Through information technology, students learn to actively construct knowledge. They also master the skills of "how to learn". As a result, their independent thinking ability, creative and innovative abilities, and cooperative ability have all been greatly enhanced. The blended teaching model of information era is to play the leading role for future educational reform.[2]

\subsection{Innovation in teaching content}

With the introduction of blended teaching model, the contents of English oral courses have been designed and implemented in a totally innovative way. Students receive systematic instructions in pronunciation, discussion, public speaking and debate and improve their abilities in content construction, cross-cultural communication and critical thinking. Please refer to table 1 for more details:

Table 1: Innovation in Teaching Content

\begin{tabular}{|c|c|c|}
\hline \multirow[t]{2}{*}{ Course } & \multicolumn{2}{|c|}{ Teaching Content } \\
\hline & core content & extended content \\
\hline $\begin{array}{l}\text { Pronunciation and } \\
\text { Communication }\end{array}$ & $\begin{array}{l}\text { 口basic pronunciation skills, such as vowels, } \\
\text { consonants, stress, linking, plosive, } \\
\text { intonation and rhythm etc. }\end{array}$ & $\begin{array}{l}\square \text { construction of conversation content, } \\
\text { with topics of hobby, family, friendship, } \\
\text { travel, city life etc. }\end{array}$ \\
\hline $\begin{array}{l}\text { Current Issue } \\
\text { Discussion }\end{array}$ & $\begin{array}{l}\text { 口basic discussion skills, such as proposing } \\
\text { topics, expressing personal views, } \\
\text { expressing agreement and disagreement, } \\
\text { dispute resolution etc. }\end{array}$ & $\begin{array}{l}\square \text { cross-cultural communication, with } \\
\text { topics of health, entertainment, politics, } \\
\text { business, environment etc. }\end{array}$ \\
\hline Public Speaking & $\begin{array}{l}\text { abasic public speaking skills, such as } \\
\text { outlining the speech, designing the opening, } \\
\text { body and ending of the speech etc. } \\
\text { avaried public speaking styles, such as } \\
\text { persuasive speech, informative speech, } \\
\text { impromptu speech etc. }\end{array}$ & $\begin{array}{l}\square \text { introduction of critical thinking skills, } \\
\text { such as credibility in speech, deduction } \\
\text { and induction in reasoning, language } \\
\text { fallacy etc. } \\
\square \text { cross-cultural communication, with } \\
\text { topics of education, technology, culture, } \\
\text { career etc. }\end{array}$ \\
\hline Debate & $\begin{array}{l}\square \text { basic debating skills, such as } \\
\text { argumentation, motion analysis, refutation, } \\
\text { debate evaluation etc. } \\
\square \text { varied debating styles, such as opening } \\
\text { government speech, opening opposition } \\
\text { speech, member speech, whip speech etc. }\end{array}$ & $\begin{array}{l}\text { aintroduction of the British parliamentary } \\
\text { debate model form } \\
\square \text { construction of debating content with } \\
\text { topics of current social issues }\end{array}$ \\
\hline
\end{tabular}


For English oral courses, the extended content is usually designed as the task for pre-class self-study. It is mainly in the form of flexible teaching resources and guarantees sufficient time for innovative activities in class, such as discussion, debate or speech making etc. The design of core content and extended content guarantee the successful application of blended teaching model and the cultivation of students' comprehensive abilities.

\subsection{Application of blended teaching model}

The development of information technology has brought many changes to the higher educational system. So far, teachers in DNUI have carried out many educational reforms. As for English oral classes, the application of information technology, such as Moocs, English dubbing software and online recording and assessing system, has gained great popularity and received wide recognition. There are other innovative designs in the pre-class, in-class and after-class teaching sections. Please refer to table 2 for more details:

Table 2: Innovation in Teaching Mode

\begin{tabular}{|c|c|c|c|}
\hline Course & Pre-class & In-class & After-class \\
\hline $\begin{array}{l}\text { Pronunciation and } \\
\text { Communication }\end{array}$ & $\begin{array}{l}\square \text { self study: Moocs of } \\
\text { pronunciation skills }\end{array}$ & $\begin{array}{l}\square \text { input of pronunciation } \\
\text { knowledge } \\
\square \text { input of communication } \\
\text { knowledge } \\
\square \text { role play }\end{array}$ & $\begin{array}{l}\square \text { self-evaluation } \\
\square \text { extended activities: } \\
\text { distinguish sounds, } \\
\text { proverb reading, } \\
\text { tongue twist practice }\end{array}$ \\
\hline $\begin{array}{l}\text { Current Issue } \\
\text { Discussion }\end{array}$ & $\begin{array}{l}\square \text { preparation: current issue } \\
\text { analysis } \\
\square \text { preparation: topic-related } \\
\text { expressions } \\
\square \text { preparation: topic sharing }\end{array}$ & $\begin{array}{l}\square \text { news presentation } \\
\square \quad \text { input of discussion } \\
\text { knowledge } \\
\square \text { presentation practice }\end{array}$ & $\begin{array}{l}\text { self-evaluation } \\
\square \text { oral practice } \\
\square \text { extended activities: } \\
\text { vocabulary practice } \\
\text { via Quizlet }\end{array}$ \\
\hline Public Speaking & $\begin{array}{l}\text { } \square \text { preparation: task-oriented } \\
\text { assignment } \\
\square \text { self study: Moocs of } \\
\text { public speaking skills } \\
\square \text { self study: Moocs of } \\
\text { critical thinking knowledge }\end{array}$ & $\begin{array}{l}\text { cross-cultural } \\
\text { communication } \\
\square \text { input of public speaking } \\
\text { knowledge } \\
\square \text { speech evaluation } \\
\text { through critical thinking }\end{array}$ & $\begin{array}{l}\text { self-evaluation } \\
\square \text { extended activities: } \\
\text { speech appreciation } \\
\text { on TED website }\end{array}$ \\
\hline Debate & $\begin{array}{l}\text { self study: Moocs of } \\
\text { debating skills }\end{array}$ & $\begin{array}{l}\square \text { input of debating } \\
\text { knowledge }\end{array}$ & $\begin{array}{l}\square \text { self-evaluation } \\
\square \text { extended activities: } \\
\text { English Debating } \\
\text { Competition }\end{array}$ \\
\hline
\end{tabular}

The pre-class section enables students to come to class prepared with proper understanding of the theoretical knowledge. In-class time is then left for the fulfilling of varies others tasks, which challenge students' abilities in knowledge application, critical thinking and cooperation. The task usually take the form of such unit project as role play, presentation, speeches or debating, followed by tongue twist practice, TED speech appreciation or debating competition after class. This kind of blended teaching model maximizes students' potential for learning and realizes the educational objectives in the information era.

\subsection{Project design in blended teaching model}

Project-based learning (PBL) is a student-centered pedagogy that involves a dynamic classroom approach in which it is believed that students acquire a deeper knowledge through active exploration of real-world challenges and problems. PBL contrasts with paper-based, rote memorization, or teacher-led instruction.[3]

The project-based teaching model has been introduced into China in the recent decades. So far, DNUI has shown a pioneering spirit in its application. Foreign language institute has designed and implemented levels of project in teaching, for example, at the course level or the unit level. As for English oral courses, please refer to table 3 for more information about project implementation in blended teaching model: 
Table 3 Project Design

\begin{tabular}{|l|l|l|}
\hline \multicolumn{1}{|c|}{ Course } & \multicolumn{2}{|c|}{ Project } \\
\cline { 2 - 3 } & \multicolumn{1}{|c|}{ Unit Project } & \multicolumn{1}{c|}{ Course Project } \\
\hline $\begin{array}{l}\text { Pronunciation and } \\
\text { Communication }\end{array}$ & $\begin{array}{l}\square \text { group discussion on different } \\
\text { topics }\end{array}$ & $\begin{array}{l}\square \text { English movie dubbing } \\
\text { competition }\end{array}$ \\
\hline $\begin{array}{l}\text { Current Issue } \\
\text { Discussion }\end{array}$ & $\begin{array}{l}\square \text { group discussion on different } \\
\text { topics }\end{array}$ & $\begin{array}{l}\square \text { round table discussion on } \\
\text { current issues } \\
\square \text { talk show }\end{array}$ \\
\hline Public Speaking & $\begin{array}{l}\square \text { speaking practice on different } \\
\text { simulated scenarios }\end{array}$ & $\begin{array}{l}\square \text { speech competition } \\
\text { Debate }\end{array}$ \\
$\begin{array}{l}\square \text { debate analysis, argument and } \\
\text { refutation }\end{array}$ & $\square$ debate competition \\
\hline
\end{tabular}

With varied discussion topics, unit projects are implemented throughout the course. Students are instructed to take full responsibility for their learning and work together to accomplish specific goals. They are constantly making choices on how to obtain, display, or manipulate information and get involved either individually or as a group. The course projects evaluate students' learning effects and improves their comprehensive qualities. With different levels of project design, students can stay focused in class and their learning efficiency has been greatly enhanced.

\section{Conclusion}

The development of information technology has brought many changes to education. In DNUI, the blended teaching model has been localized with positive effects in course construction. The series of oral courses present the efforts to improve students' speaking abilities and reflections on the course reform will give light on its future development.

\section{References}

[1] GongXiu huan. Education Modernization[J]. Research on Blended Teaching Model for University English Major Education, 2019, 6(30):190.

[2] MaJian yun. Research on the Development and Guarantee System of Blended Teaching Model for Higher Education[D]. Chongqing: Xinan University, 2018.

[3] Project-based learning. https://en.wikipedia.org/wiki/Project-based_learning. Accessed July 14, 2019. [Wikipedia] 